\title{
The Book of Job: A Greco-Hebrew Rhetorical Drama
}

\author{
John Kuriakose ${ }^{1}$ \\ ${ }^{1}$ Department of Foreign Languages, Albaha University, Al-Baha, KSA \\ Correspondence: John Kuriakose, Department of Foreign Languages, Albaha University, Al-Baha, KSA. E-mail: \\ johnkuriakose59@gmail.com
}

Received: February 15, 2016 Accepted: April 7, 2016 Online Published: April 28, 2016

doi:10.5539/ells.v6n2p72 URL: http://dx.doi.org/10.5539/ells.v6n2p72

\begin{abstract}
The Book of Job, as a biblical book, which "does not have a literary parallel in ancient Near Eastern wisdom literature," continues to be an enigma to scholars. Its puzzles mainly concern its roots, genre and structure. Though the book exhibits a variety of generic features creating the impression of a work of multiple authors, a careful look at its form reveals that for its structural organization, its author has relied much on the form of Greek rhetoric, which Aristotle explains in his work, On Rhetoric, of the mid-350's BCE. Thus, as a testament of Judeo-Christian faith and the Hebrew concept of divine justice, it has the structural frame of the Athenian judicial rhetoric. Also, it has the generic features of the Greek dramatic, Hebrew epic and fairytale traditions. These features undermine the theory of multiple authorship of the book. Presumably, it was written by a Jew who was well-versed in Hebrew traditions and faith, well-informed on the literary traditions of the time, and well-trained in the art of Greek rhetoric and drama. And hence, The Book of Job deserves to be called a Greco-Hebrew Rhetorical Drama.
\end{abstract}

Keywords: Aristotle, Bible, genre criticism, Greek rhetoric, religious drama

\section{Introduction}

The Book of Job is beset with enigmas. Its puzzles mainly concern its roots, genre and structure. Those who look for the dominant genre of the book find in it a unique form of drama, which, after giving an intense experience of a tragedy, takes an unexpected U-turn to a comic ending. Its folktale-like prologue and epilogue in prose, in sheer contrast with its poetic chain of dialogues, have made some critics speculate that "the Job of the prologue is not the Job of the dialogue," "some parts of the book are less genuine than others" (Smick, 1986, p. 135), and that it is a work of multiple authors. In reference to the genre of the book, Epithets like "wisdom literature," "divine drama," "imaginative drama," "tragedy," "comedy," "interplay of tragedy and comedy," "gentile folktale," and "a kind of legal proceedings" have been tried out. This paper is an attempt to find a single key to these puzzles, within the structural organization of the book.

\section{Genre Criticism}

The diversity of views on the generic status of the book calls for a fresh look into this aspect. In this regard, Andrew E. Hill observes that "a single genre classification cannot adequately describe the literary form of the book" because it does not have a literary parallel in ancient Near Eastern wisdom literature (Hill, 2005, p. 269). He points out that The Book of Job exhibits a variety of generic features such as proverb or wisdom saying, riddle, lament, hymn, dialogue, lawsuit or trial speech, soliloquy, and rhetorical features like irony, sarcasm, simile, metaphor and rhetorical questions. He writes: "Given this array of genres and literary features, Job has been defined as epic drama, epic history, lament, disputation, judicial process, comedy, tragedy, and parable, among others" (Hill, 2005, p. 269). When Manser includes the book in wisdom literature, with other biblical books like Proverbs, Ecclesiastes and the Song of Solomon, Edward F. Edinger calls it a "divine drama" (Edinger, 1992, p. 560), and Northrop Frye, an "imaginative drama" (qtd. in Alonso Schökel, 1997, p. 45). When Christopher Frye finds in it an interplay of tragedy and comedy, Whedbee emphatically calls it a comedy, and Louis Alonso Schökel calls it "dramatic," but not fitting into the current concept of literary drama, which is "very precise and limited" (Schökel, 1997, p. 45). For Pauline Shelton, the structure of the book is "essentially dramatic" (Shelton, 1999, p. 70), but it does not fit into a tragic frame because the "blameless and upright" character of Job does not have any tragic flow, and the story has a happy ending (Shelton, 1999, p. 69-70). Ronald Quillo holds the view that the book is based on "a gentile folktale of 6th century BCE" (Quillo, 1991, p. 
213), whereas for Max Rogland, it is "a kind of legal proceedings" (Rogald, 2009, p. 51).

Literary works that are enigmatic by form refuse to be explained in terms of existing genres. Ivan Todorov refers to this problem in his Introduction to a la Literature Fantastique, and observes that each literary work "modifies the whole set of possibilities" and "changes the species" (qtd. in Scholes, 1975, p. 128). In the wake of the diversity of views on the generic status of The Book of Job, Brent D. Sandy \& Donald L. Giese Jr. observe: "...the Bible has literary codes that reveal how authors were expressing the word of the LORD and what they intended to communicate. Understanding what these codes are and the significance of them will help keep readers from misinterpreting Scripture and will guide them into correct interpretation and application" (Sandy \& Giese, 2005, p. 2). Branson L. Woodard \& Michael E. Travers recommend that in genre criticism, the "dynamics of form and content must be kept together" (Woodard \& Travers, 2005, p. 31). And referring to the emergence of rhetorical criticism and its relevance in genre criticism and biblical scholarship, they observe: "Genre criticism is the process of identifying in a text the range of literary-rhetorical features that make the text one type of writing and not another - that determine where on the literary 'menu' a text should be listed" (Woodard \& Travers, 2005, p. 29). As ancient writings are mostly a product of oral tradition, rhetorical critics would examine such a text "as if its audience were listeners to a speech rather than readers of a scroll or book" (Woodard \& Travers, 2005, p. 32). The presence of a long chain of speeches in The Book of Job calls for special attention from this perspective as well.

For genre criticism, scholars generally follow the principles laid down by Greek critical scholarship in relation to epics and tragedies. The Book of Job has all the elements of classical tragedy. However, the concept of suffering it presents is not Greek; rather, it is something religious. As J. Cheryl Exum points out, in Job, "the suffering, the misery, the evil, and the inexplicable in the world are part of an inscrutable, larger plan for the good." He writes: "With the biblical literature, we remain in the world of bold assertions about the possibilities of freedom and the demands of transcendence." In his view, "Where there is justice there can be no tragedy" (Exum, 1992, p. 7). The book presents God himself as a Character; after extensive, argumentative speeches among the other characters, God appears and pronounces a just and merciful judgment. And it is on this basis that Edinger calls the book a religious drama.

As "time in religion is beyond human discernment," a religious drama would not confine itself to the concept of unities of the worldly drama. The discourses and replies of Job and his friends and the speeches of Elihu and God - stretched over 40 chapters - obviously seem to have taken place over a period of twenty four hours. But the book as a whole does not observe the other two unities of worldly drama: spatially it belongs to the earth and the heaven, and temporally it is stretched over a long period. However, the intersection of man and God in the book shows the influence of the Greek tragic tradition. As Helaine L Smith observes, “... Greek tragedy presents the intersection of god and man and asserts the limitation of human understanding and endeavor..." (Smith, 2006, p. 1).

How do we account for the tragic/comic problematic of the play? In Exum's view, "The Job of the folktale who acquiesces is not tragic, but the Job of the poem who argues tirelessly against his friends and what he perceives as God's injustice is profoundly so." Exum writes:

At some point in tragedy, a catastrophe occurs. Disaster does not have to be the final word (as witnessed by the Oresteia, Oedipus at Colonus, and even the book of Job), but it usually breaks the hero, who dares to defy the universe. .. Often a tragic hero responds to disaster-Oedipus to the plague, Saul to a crisis of leadership, Jephthah to a military emergency — and unleashes more disaster. (Exum, 1992, p. 11)

...Job insists on his integrity and defies: "He may slay me; I am without hope. Yet I will defend my conduct to his face" (Job, 13:15). (Exum, 1992, p. 13)

However, in Exum's view, the resolution of the book with Job's restoration to prosperity with a bonus is not such stuff as tragedies are made of. But she does not find it "sufficient in power or conviction to transform the book into a comedy" either, because the dialogue in Job brings "cosmic terror, as well as human heroism, into such stark relief." In her view, "comic heroes do not reach such heights" (Exum, 1992, p. 13).

Another puzzle is the textual organization of the book which begins with a prologue and ends in an epilogue - both in prose - and a long chain of dialogues in poetry embedded between them. This makes scholars like Ahalya Brenner arrive at a multiple authorship theory. Robert Polzin finds a "confrontation of inconsistencies" in the structure and content of the book, but suggests that any attempt to remove this inconsistency would be an "academic failure of nerve" (Brenner, 1989, p. 183). And as discussion moves on, puzzles get piled up. Andrew E. Hill fittingly remarks: "As a blend or mix of several genres and speech forms, The Book of Job almost defies literary description" (Hill, 2005, p. 268). 


\section{Reliance on Greek Rhetoric}

A careful look at the form of The Book of Job reveals that for its structural organization, its author has relied much on the form of Greek rhetoric, which Aristotle explains in his work, On Rhetoric of the mid-350's BCE. This source would answer the puzzle regarding the structural organization of The Book of Job, and shake the multiple author theory regarding its composition.

\subsection{Job in Prologue and Aristotle's Conception of Happiness}

To begin with, the state of Job before the catastrophes occur, described in verses 1 to 5 of the prologue of chapter 1, goes in parallel to Aristotle's conception of happiness discussed in Chapter 5 of On Rhetoric, "Ethical Topics for Deliberative Rhetoric," written in the mid-350's BCE. Defining happiness, Aristotle writes:

3. Let happiness be [defined as] success [eupraxia] combined with virtue, or as self-sufficiency [autarkeia] in life, or as the pleasantest life accompanied with security, or as abundance of possessions and bodies, with the ability to defend and use these things; for all people agree that happiness is pretty much one or more of these. (qtd. in Kennedy, 2007, p. 57)

The Job of the prologue, no doubt, possesses all the above qualifications. About Job's "virtue," the book says: "... [there is] none like him in the earth, a perfect and an upright man, one that feareth God, and escheweth evil?" (1:8). About Job's "security," Satan comments: God has "made a hedge about him, and about his house, and about all that he hath on every side" (1:10). In terms of "possession"/ wealth, he had "seven thousand sheep, and three thousand camels, and five hundred yoke of oxen, and five hundred she asses, and a very great household; so that this man was the greatest of all the men of the east" (1:3).

In the following passage, Aristotle continues on the subject of happiness by listing its "parts."

4. If happiness is something of this sort, it is necessary for its "parts" to be good birth, numerous friendships, worthy friendships, wealth, good children, numerous children, a good old age, as well as the virtues of the body (such as health, beauty, strength, physical stature, athletic prowess), reputation, honor, good luck, virtue; for a person would be most self-sufficient if he had these goods, both internal and external; for there are no others beyond these. Internal goods are those relating to the mind and the body, while good birth and friends and wealth and honor are external. And further, we [all] believe that the power to take actions and good luck should be present; for thus life would be most secure." (qtd.in Kennedy, 2007, p. 57)

The description of Job in Prologue, Chapter 1 of The Book of Job, meets all the above requirements. Regarding "birth" and "friendship," Job was blessed with the best friends and was presumably of noble birth. He was blessed with "good children:" "seven sons and three daughters" (1:2). The book says, "And his sons went and feasted [in their] houses, every one his day; and sent and called for their three sisters to eat and to drink with them. And it was so, when the days of [their] feasting were gone about, that Job sent and sanctified them, and rose up early in the morning, and offered burnt offerings [according] to the number of them all" (1:4-5).

Regarding the strength of Job, Eliphaz reminds him: "Behold, thou hast instructed many, and thou hast strengthened the weak hands. Thy words have upholden him that was falling, and thou hast strengthened the feeble knees" (4:3-4). And in terms of reputation, he "was the greatest of all the men of the east" (1:3). Of the other qualifications Aristotle prescribes - age, health, beauty, honour and good luck - Job was richly blessed with all; but about his "physical stature" and "athletic prowess," the book does not say anything. However, the Aristotelian definition of happiness perfectly applies to the Job of the prologue and the epilogue.

\subsection{Job and Judicial Rhetoric}

In On Rhetoric, Aristotle identifies three branches of rhetoric: 1. Deliberative rhetoric, which was used to persuade the listener; 2. Epideictic rhetoric or ceremonial rhetoric; and 3. Judicial rhetoric, which was used in court cases. Of these three types, The Book of Job closely follows the pattern of the judicial rhetoric. According to Aristotle, the elements of judicial rhetoric are prooemion or prologue, diegesis or narration, interrogation and epilogue. The Book of Job follows the progression of these elements of judicial rhetoric.

Chapter 1 of Job begins with a prologue or prooemion in 5 verses, which presents a highly condensed picture of a contented Job; in the diegesis or narration that follows, it narrates the first catastrophic test of Job in the remaining 17 verses of the same chapter, the second catastrophic test in the first 10 verses of chapter 2, and the highly sympathetic response of Job's friends to the troubles that have come upon him, in the last 3 verses of the same chapter. The diegesis that continues presents Job's discourse, the speeches by his friends and Elihu, and Job's replies to them in chapters 3 to 37; "interrogation" by God in chapters 38 to 41; and Job's confession and 
surrender in the first 6 verses of chapter 42. And the book ends with an epilogue in 11 verses, which presents God's judgment that acquits Job but punishes his friends, and restores all the past glory of Job with a bonus.

According to Aristotle, "the prooemion is the beginning of a speech, what a prologue is in poetry and a proaulion in flute-playing; for all these are beginnings and, as it were, pathmakers for one who is continuing on" (qtd. in Kennedy, 2007, p. 231). In the Greek tradition of rhetoric, it is Epideictic rhetoric or ceremonial rhetoric, which was used to praise (or blame) someone. But in the Book of Job which is modeled on judicial rhetoric, in the prologue, the author is praising the virtues of Job. Aristotle observes: "As for the prooemia of judicial speeches, one should grasp that they have the same effect as the prologues of plays and the prooemia of epic poems" (qtd. in Kennedy, 2007, p. 233).

\subsection{Use of Rhetorical Questions}

Profuse use of rhetorical questions - another unique artistic feature of The Book of Job - is also in tune with the judicial rhetoric of the Athenian judicial procedure. Kennedy notes: "rhetorical questions, not expecting an answer, are far more common" in the Athenian judicial procedure (Kennedy, 2007, p. 247). In chapters 38 to 41 of The Book of Job, God interrogates Job. The interrogation begins in the following way: "Who [is] this that darkeneth counsel by words without knowledge? Gird up now thy loins like a man; for I will demand of thee, and answer thou me" (38:2-3). This interrogation involves a string of rhetorical questions: "Where wast thou when I laid the foundations of the earth? Declare, if thou hast understanding. Who hath laid the measures thereof, if thou knowest? Or who hath stretched the line upon it?" (38:4-5). Chapter 38 and 39 are only rhetorical questions. Chapter 40 begins with the question: "Shall he that contendeth with the Almighty instruct [him?] he that reproveth God, let him answer it" (40:2). Job does not answer any of these questions; rather, he humbly responds to God: "Behold, I am vile; what shall I answer thee? I will lay mine hand upon my mouth. Once have I spoken; but I will not answer: yea, twice; but I will proceed no further" (40:4-5).

\subsection{Function of Epilogue}

Aristotle would permit the use of epilogue in a judicial rhetoric as well as deliberative speeches "where the audience needs a recapitulation of the arguments." According to Aristotle, the epilogue in a judicial rhetoric does four things: 1. "Disposing the hearer favorably toward the speaker and unfavorably toward the opponent;" 2. "Amplifying and minimizing;" 3. "Moving the hearer into emotional reactions;" and 4. "Giving a reminder of the chief points in the argument" (qtd. in Kennedy, 2007, p. 249). And about the way a judicial rhetoric concludes, Aristotle remarks: "After he has shown himself to be truthful and his opponent false, the natural thing is [for a speaker] to praise and blame and drive home the point. One should aim at showing one or the other of two things: either that the speaker is a good man in terms of the issues or that he is good generally; or either that the opponent is a bad man in terms of the issues or that he is bad generally" (qtd. in Kennedy, 2007, p. 249).

The epilogue of Job rightly fits into the above requirements and functions listed by Aristotle. It serves the purpose of "recapitulation." It disposes the reader favourably towards Job by amplifying his virtues and it criticizes his opponents/friends. God reminds Job's friends of their mistakes, asks them to make amends for it, and showers blessings in abundance on Job, which really moves the reader. And the book concludes the way Aristotle expects a judicial rhetoric to conclude. Job is proved to be true, and his opponents false; Job is praised, and his opponents are blamed.

The epilogue of Job begins as follows: "And it was so, that after the LORD had spoken these words unto Job, the LORD said to Eliphaz the Temanite, My wrath is kindled against thee, and against thy two friends: for ye have not spoken of me the thing that is right, as my servant Job hath (42:7). In the rest of the epilogue, God reprimands Job's friends for not saying right things about God and His servant Job; and asks them to offer "seven rams and seven bullocks" for expiating their sins. God says, "and my servant Job shall pray for you; for him will I accept" (42:8). And then, the reader is told how the Lord made Job prosperous again, and gave him twice as much as he had before. His brothers and sisters and everyone who had known him came and ate with him in his house, they consoled him over all the troubles he had, and gave him pieces of silver and gold as presents.

The epilogue says how God blessed Job in the latter part of his life with "fourteen thousand sheep, and six thousand camels, and a thousand yoke of oxen, and a thousand she asses" (42:12). And then it says: "And in all the land were no women found so fair as the daughters of Job: and their father gave them inheritance among their brethren" (42:15). Then it concludes as follows:" After this lived Job an hundred and forty years, and saw his sons, and his sons' sons, even four generations. So Job died, being old and full of days (42:16-17).

However, in terms of the concept of God, the author of $J o b$ considerably deviates from the Aristotelian concept: 
when Aristotle's God is the "unmoved mover," the God of The Book of Job is one who shares and responds to the emotions of humans. Here, it is evident that the author of the book is relying on the structural frame of a Greek artistic tradition in order to drive home the Hebrew concept of God.

\section{Fallacy of the Multiple Author Theory}

The peculiar compositional feature of the Book of Job with its prose prologue and epilogue contrasting significantly with the poetic dialogues led scholars like William M. Schniedewind and Mathewson to presume that it is the work of multiple authors. In Schniedewind's view, the narrative prose introduction of The Book of $J o b$ (Chapters 1-2) was added in the Persian or Hellenistic period: that is, the first original form of the book was the poetic section that consisted of chapter 3-41, and the narrative prose pieces were later additions (Schniedewind, 2004, p.179). In Mathewson's view, there exists a tension between the prose epilogue and the poetic sections and the book has "multiple beginnings and Endings" (Mathewson, 2006, p. 38). And Alhalya Brenner finds the link between the opening narrative portion of the book and the succeeding poetic portion "puzzling" (Brenner, 1989, p. 37). But Kennedy's finding on the development of artistic prose in Greece in the 5th and 4th centuries points to the fallacy of these views. Kennedy's observation is that "the development of artistic prose in Greek ... was largely a matter of the purification of diction and regularization of syntax into an efficient, elegant tool of expression" (Kennedy, 2007, p. 198). And in Aristotle's view, it was a way of making the language "unfamiliar." Hence, the appearance of prose in the prologue and epilogue of The Book of Job, the poetic nature of the dialogues, and the folktale-like beginning and ending of the book need not necessarily make one presume that the book is a work of multiple authors; rather, it may be viewed as a way of "defamiliarization" or making things "unfamiliar," as Aristotle would view it.

\section{Time of Composition}

With respect to the time of composition of On Rhetoric George A. Kennedy observes that it was composed "in the third quarter of the fourth century B.C.E. as a text for lectures he planned to give in his philosophical school" (Kennedy, 2007, p. x). And in his view, "Aristotle was perhaps the first person to recognize clearly that rhetoric as an art of communication was morally neutral, that it could be used for either good or ill." Here, he is referring to the three important means of persuasion which Aristotle mentions in the second chapter of his treatise On Rhetoric. They are: 1. "Logos," which means "logical argument;" 2. "Bthos," which means "the projection of the speaker's character;" and 3. "Pathos," which means awakening the emotions of the audience" (Kennedy, 2007, p. $\mathrm{x})$. The Book of Job is fully exploiting all these possibilities.

How could the Greek tradition influence the creation of a Hebrew book which was believably produced somewhere in the Israelite Kingdom? It is on scholarly domain that in the mid-fourth century, Alexander the Great of Macedonia conquered the Persian Empire, and consequently, the Jews came under his rule. During this period known as Hellenistic period, the Greek culture dominated the region. Scholars agree that many books of the Bible belong to this period. The twentieth century excavation of the Dead Sea scrolls--many Old Testament documents and fragments preserved by the Qumran sect of Jews, in caves near the Dead Sea--included a Greek version of The Book of Job as well. In this connection Laure notes that the Wisdom of Solomon, like Proverbs and Ecclesiastes, was composed in the name of the famous Hebrew monarch in the period of the Hasmonean dynasty (147-37 BC) and it was written in Greek, "probably by a Jew of Alexandria who was trained in Greek rhetoric and philosophy, and whose knowledge of the LXX is apparent in his writing" (Old Testament Life and Literature). All these details suggest that The Book of Job was written by a Jew who was well-versed in Hebrew traditions and faith, well-informed on the literary traditions of the time, and well-trained in the art of Greek rhetoric and drama.

\section{Other Correspondences}

The Book of Job shares some of the features of the literary epic of the Hebrew tradition. Like the hero of the Hebrew epic, Job "passes through an ordeal to prove his worth" and proves that human beings are "sufficient objects of interest who is in pursuit of honour" (Watson, 1984, p. 84). Another epic feature of the book is that it is "a lengthy poem" (Watson, 1984, p. 85). In 1957, N. M Sarna, in his article "Epic Substratum in the Book of Job" observed: "traces of epic remain, even in a book as late as Job" (qtd. in Watson, 1984, p. 85). And referring to the use of prose, Talmon has noted that it is something which the ancient Hebrew writers "purposefully nurtured and developed... to take the place of the epic genre" (qtd. in Watson, 1984, p. 85).

Walter C. Kaiser finds in the book many stylistic features in common with the other biblical narratives. Its scenes that are set with "the pervasive presence of God," the appearance of God as a character, the simple plot of the "classical pyramid pattern," the movement of action from "a peaceful initial situation" to "the climax where the decisive step determining the outcome of the conflict" and back to "a tranquil situation at the end" are such 
features (Kaiser, 2005, pp. 71-72).

\section{Conclusion}

To conclude, The Book of Job, while being a testament of Judeo-Christian faith and the Hebrew concept of divine justice, closely follows the structural pattern of the Athenian judicial rhetoric of the 5th century BCE, in unison with the generic features of the Greek dramatic, Hebrew epic and fairytale traditions. By virtue of this multidimensional but clearly defined structure the book defies the multiple author theory and deserves to be called a Greco-Hebrew Rhetorical Drama.

\section{References}

Brenner, A. (1989). Job the Pious? The Characterization of Job in the Narrative Framework of the Book. Journal for the Study of the Old Testament, 43, 37-52. http://dx.doi.org/10.1177/030908928901304303

Edinger, E. F. (1992). Transformation of the God-Image: an Elucidation of Jung's Answer to Job. Toronto: Inner City Books.

Exum, J. C. (1992). Tragedy and Biblical Narrative: Arrows of the Mighty. Cambridge UP. http://dx.doi.org/10.1017/cbo9780511520358

Hill, A. E. (2005). Non-Proverbial Wisdom. In. Sandy, B. D., \& Giese, D. L. (Eds.), Cracking Old Testament Codes: A Guide to Interpreting the Literary Genres of the Old Testament (pp. 255-280). Nashville: Broadman and Hallman Publishers.

Kaiser, W. C. (2005) Narrative. In. Sandy, B. D., \& Giese, D. L. (Eds.), Cracking Old Testament Codes: A Guide to Interpreting the Literary Genres of the Old Testament (pp. 69-88). Nashville: Broadman and Hallman Publishers.

Kennedy, G. A. (2007). Aristotle on Rhetoric. (Trans. with introduction, notes and appendices). New York: Oxford UP.

Laure, G. A. (1968). Old Testament Life and Literature. Retrieved from http://infidels.org/library/modern/gerald_larue/

Manser, M. H. (2009). Critical Companion to the Bible: A Literary Reference. New York: Facts and File Inc.

Mathewson, D. (2006). Death and Survival in the Book of Job: Desymbolization and Traumatic Experience. New York: T \& T Clark International.

Polzin, R. (1974). The Framework of Job. Interpretation, 28(2), 182-200. http://dx.doi.org/10.1177/002096437402800205

Quillo, R. (1991). Naked Am I: Psychological Perspectives on the Unity of the Book of Job. Perspectives in Religious Studies, 213-222.

Rogland, M. (2009). The Covenant in the Book of Job. Criswell Theological Review, 7(1), 49-62.

Sandy, B. D., \& Giese, D. L. (Eds.). (2005). Cracking Old Testament Codes: A Guide to Interpreting the Literary Genres of the Old Testament. Nashville: Broadman and Hallman Publishers.

Schniedewind, W. M. (2004). How the Bible Became a Book: The Textualization of Ancient Israel. Cambridge: Cambridge UP. http://dx.doi.org/10.1017/CBO9780511499135

Schökel, A. L. (1997). Toward a Dramatic Reading of the Book of Job. Semeia, 7, 45-61.

Scholes, R. (1974). Structuralism in Literature: An Introduction. New Haven: Yale UP.

Shelton, P. (1999). Making a Drama out of a Crisis? A Consideration of the Book of Job as a Drama. Journal for the Study of the Old Testament, 83, 69-82.

Smick, E. B. (1986). Semeiological Interpretation of the Book of Job. Westminster Theological Journal, 48, 135-149.

Smith, H. L. (2006). Masterpieces of Classical Greek Drama. London: Greenwood Press.

The King James Version of the Hebrew Bible. Retrieved from http://www.davince.com/bible

Watson, W. G. E. (1984). Classical Hebrew Poetry: A Guide to its Technique. Sheffield: JSOT Press.

Whedbee, W. (1977). The Comedy of Job. Semei, 1-39.

Woodard, B. L., \& Travers, M. E. (2005). Literary Forms and Interpretation. In. B. D. Sandy \& D. L. Giese (Eds.), Cracking Old Testament Codes: A Guide to Interpreting the Literary Genres of the Old Testament 
(pp. 29-44). Nashville: Broadman and Hallman Publishers.

\section{Copyrights}

Copyright for this article is retained by the author(s), with first publication rights granted to the journal.

This is an open-access article distributed under the terms and conditions of the Creative Commons Attribution license (http://creativecommons.org/licenses/by/3.0/). 